\title{
Geochemistry of some banded iron-formations of the archean supracrustals, Jharkhand-Orissa region, India
}

\author{
H N Bhattacharya, ${ }^{1, *}$, Indranil Chakraborty ${ }^{1}$ and Kaushik K Ghosh ${ }^{2}$ \\ ${ }^{1}$ Department of Geology, Presidency College, 86/1 College Street, Calcutta 700 073, India. \\ ${ }^{2}$ Department of Geology, Jogamaya Devi College, 92 S.P. Mukherjee Road, Calcutta 700 026, India. \\ *e-mail: hbaruamu@vsnl.net
}

\begin{abstract}
Banded iron-formations (BIF) form an important part of the Archean supracrustal belts of the Jharkhand-Orissa region, India. Major, trace and REE chemistry of the banded iron-formation of the Gandhamardan, Deo Nala, Gorumahisani and Noamundi sections of the Jharkhand-Orissa region are utilized to explore the source of metals and to address the thermal regime of the basin floor and the redox conditions of the archean sea. Hydrothermal fluids of variable temperatures might have contributed the major part of the Fe and other trace elements to the studied banded iron-formations. Diagenetic fluids from the sea floor sediments and river water might have played a subdued role in supplying the Fe and other elements for the banded iron-formations.
\end{abstract}

\section{Introduction}

Banded iron-formations form a major component of the Precambrian greenstone belts and similar supracrustals the world over (Melnik 1982; Polat and Frei 2005). Major, trace and rare earth element geochemistry of Precambrian banded iron-formations is utilized to decipher the contemporaneous seawater chemistry and the evolution of the terrestrial atmospherehydrosphere-lithosphere system (Klein and Beukes 1989; Derry and Jacobsen 1990; Danielson et al 1992; Rao and Naqvi 1995; Bau and Dulski 1996; Kato et al 1996; Trendall and Blockley 2004; Bolhar et al 2004). Such studies are carried out on bulk samples of banded iron-formations. However, it is known that the intake capacity of chert/quartz for trace and rare earth elements is negligible (Rao and Naqvi 1995), and such elements are incorporated in the iron bearing oxide, carbonate, silicate and sulphide phases in banded iron-formations (Graf 1978; Alibert and McCulloch 1993). Thus trace and REE chemistry of the iron bearing phases in banded iron-formations, therefore, are likely to provide representative chemical signatures of banded iron-formations.

Banded iron-formations are the most common components in the Archean supracrustal belts (Iron Ore Group, Banerji 1977) of the JharkhandOrissa region, India (figure 1). Most of these banded iron-formation horizons belong to the oxide facies banded iron-formations as defined by James (1954), but silicate facies banded iron-formations are also locally developed. Majumder et al (1982), argued in favour of a chemical-sedimentary origin of these banded iron-formations. Representative banded iron-formations from four different localities (figure 1) were analyzed for major elements and the oxide phases respectively, for trace and rare earth elements (REE) in XRF, EPMA and LA-ICPMS. The geochemical results of the banded iron-formations are used to address questions regarding the thermal regime of the basin floor, the redox conditions of the sea bottom water and source of the $\mathrm{Fe}$ and other elements in these banded iron-formations.

Keywords. Archean; banded iron-formation; geochemistry; hydrothermal fluids; seawater. 


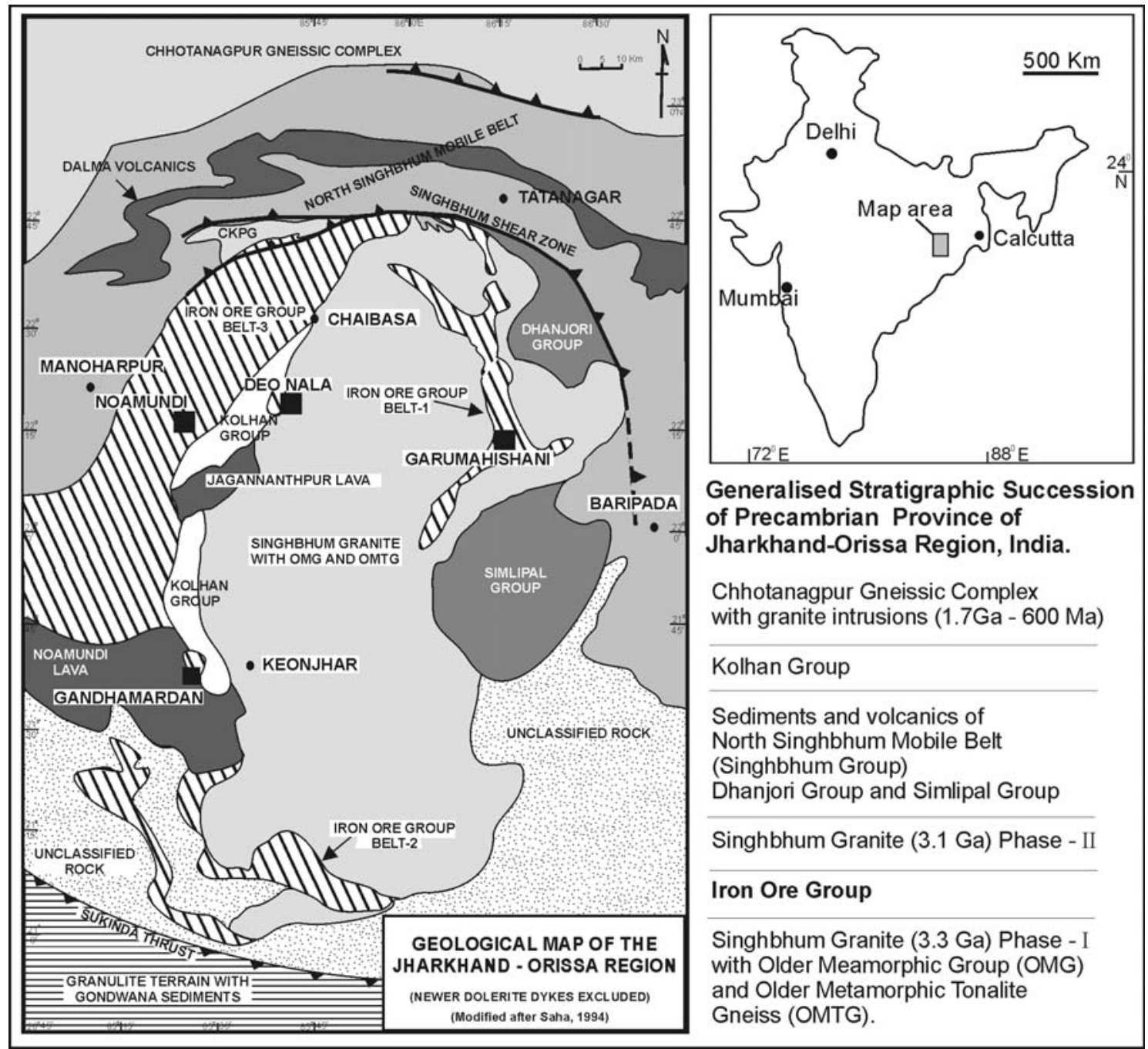

Figure 1. Geological map of Jharkhand-Orissa region, India showing the study areas.

\section{Geology of the banded iron-formation bearing supracrustals}

Archean supracrustal belts containing banded ironformations in the Jharkhand-Orissa region, India are commonly referred to as Iron Ore Group (Sarkar and Saha 1962). These belts skirt the Singhbhum Granite massif in the east, south and west (figure 1). The major ones amongst these are:

\section{Belt 1: Kudada-Patka-Gorumahisani-Badam-} pahar in the east,

Belt 2: Tomka-Daiteri and Malayagiri-Sundarmundi in the south and southwest,

Belt 3: Jamda-Koira in the west.

Besides, there are two isolated occurrences, one is at the Deo Nala section and the other forms the Gandhamardan hill near Keonjhar (figure 1).

The rocks of the Iron Ore Group unconformably overlie the early phases of the Singhbhum Granite massif, which was emplaced c 3350-3400 Ma ago $(\mathrm{Pb}-\mathrm{Pb}$ and $\mathrm{Rb}-\mathrm{Sr}$ ages of Moorbath and Taylor 1988). A late phase of the Singhbhum Granite intruded the Iron Ore Group of rocks at Gorumahisani-Badampahar and Deo Nala and are dated $3120 \pm 100$ and $3145 \pm 282 \mathrm{Ma}$, respectively (Sm-Nd ages, in Saha 1994 and Paul et al 1991). The banded iron-formations at Deo Nala sections actually occur as rafts of various sizes within intrusive granite. The age of these intrusive granites mark the upper limit of banded ironformations of the Iron Ore Group of rocks in the Gorumahisani-Badampahar and Deo Nala sections in the Jharkhand-Orissa region. However, the depositional age of banded iron-formations in the Noamundi and Gandhamardan areas, because of the absence of late intrusive granites remain controversial (Saha 1994).

Banded iron-formations in the eastern and southern belts (figure 1) overlie a thick succession of conglomerate-sandstone (fuchsite bearing 


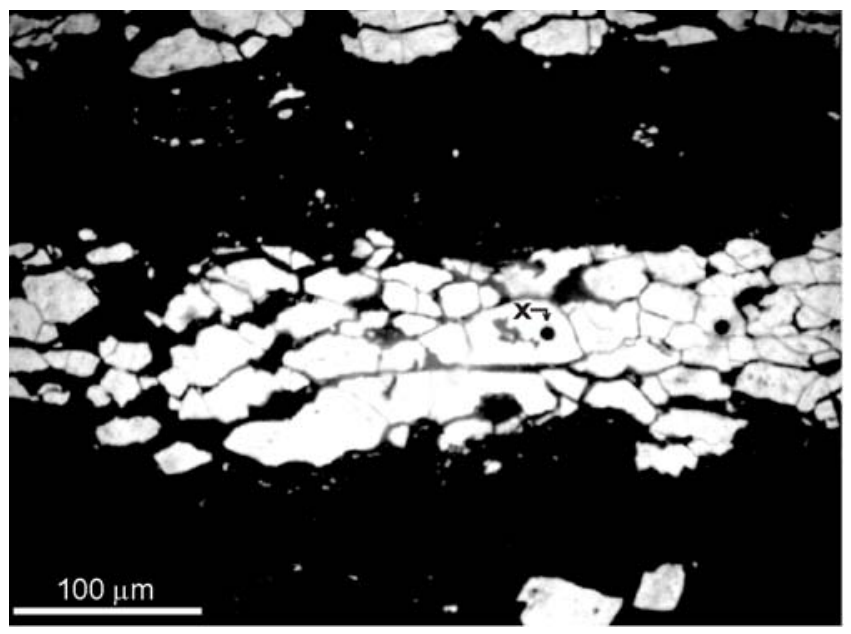

Figure 2. Alternating bands of martitized magnetites and chert. ' $\mathrm{X}$ ' represents laser ablation pit.

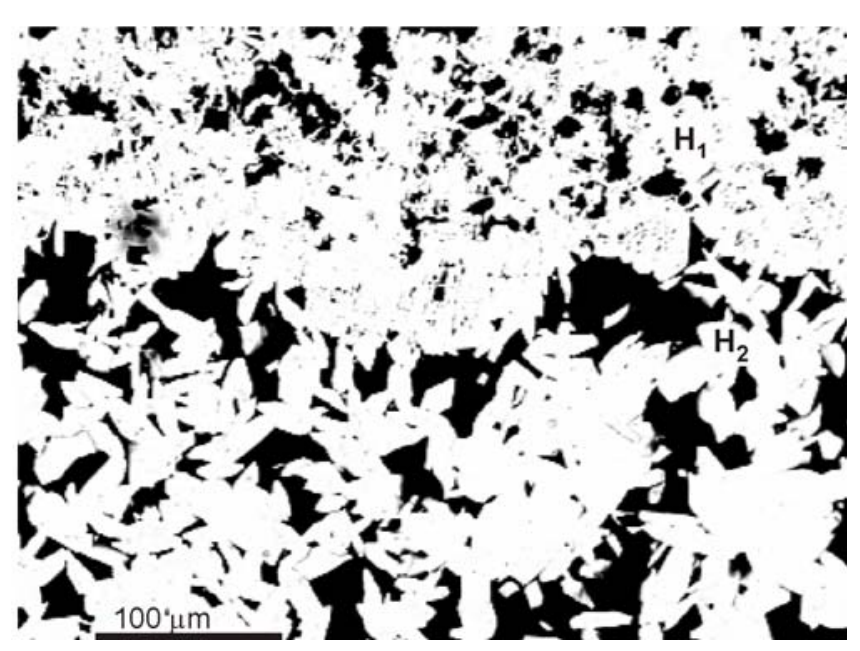

Figure 3. Growth of secondary microplaty hematites (H2) around primary hematite grains (H1), Noamundi.

at places)-chert-tuff-basic volcanics. Banded ironformations in the western belt (figure 1) are underlain by tuff, basic to acid volcanics, conglomerate, sandstone and dolomite, and overlain by shale and tuff. All these belts experienced multiple phases of deformation and low greenschist facies metamorphism.

The banded iron-formations are well-banded rocks consisting of millimeter to centimeter thick alternating iron-rich and silica-rich layers (mesobands of Trendal 1973). Both oxide and silicate facies iron-formations (cf. James 1954) are present in the Kudada-Patka-GorumahisaniBadampahar belt. There are millimeter or less thick iron-rich layers containing magnetite (variously martitized) or iron-silicates such as stilpnomelane or grunerite, alternating with chert/quartz rich layers. Iron-silicate layers may contain fewer carbonate grains. Apatite and monazite grains were not identified in the studied specimens. Occasional intercalations of fine pyroclastic layers are not uncommon (Majumder et al 1982). Banded iron-formations of the Deo Nala, Noamundi and Gandhamardan sections are represented by oxide facies iron-formation of James (1954). Apart from martitized magnetite, Noamundi iron-formations are composed of primary hematites. Recrystallization of cryptocrystalline oxide and silicate phases to equant larger grains is common. Layer- parallel, stretched, large martitized magnetite grains with equilibriated grain contacts, defining thin iron-rich layers in banded iron-formations (figure 2) are common in Deo Nala section. Grain enlargement and growth of secondary microplaty hematite grains around pre-existing large martitized magnetite or hematite grains (figure 3 ) are common in all the ironformations.

\section{Geochemistry of the banded iron-formations}

\subsection{Sampling and analytical techniques}

The samples studied here were collected from the Gorumahisani, Noamundi, Gandhamardan and Deo Nala sections (figure 1). Proper care was taken to collect the best possible fresh samples, particularly from areas where the iron-formations are not affected by hydrothermal overprinting, and ironore mineralizations in close viscinity are absent. Samples with mesoband thicknesses below $3 \mathrm{~mm}$ were selected for major and trace elemental analysis. Powder bulk samples of banded iron-formation for XRF and polished blocks of iron-rich mesobands for LA-ICPMS analyses were prepared from very close parts in respective hand specimens. Magnetite grains with minimum martitization and primary hematite grains without overgrown secondary microplaty hematite were initially selected under microscope for LA-ICPMS analyses.

XRF analysis for major elements was carried out in a Panalytical Magix-Pro machine at the Divison of Earth and Planetary Sciences, Hokkaido University, Japan. Glass beads were used to measure major elements. Powdered samples were heated at $800^{\circ} \mathrm{C}$ for $2 \mathrm{~h}$, and were mixed with flux (dilithium tetraborate anhydrous) in the weight ratio of 1:2 before making beads. The target grains of iron-oxide phases (martitized magnetite) in ironoxide rich layers of polished blocks of banded ironformation were analyzed for trace and rare earth elements using an Agilent HP 4500 quadrupole ICP-MS with a UP213 Nd:YAG laser probe (LAICPMS) with beam resolution as low as $5 \mu \mathrm{m}$ at the Centre for Ore Deposit Research (CODES), 
Table 1. Major element chemistry (in wt\%) of the banded iron-formations of Archaean supracrustal belts (Iron Ore Group) of Jharkhand-Orissa region.

\begin{tabular}{|c|c|c|c|c|c|c|c|c|c|c|c|c|c|}
\hline \multicolumn{7}{|c|}{ Gandhamardan } & \multicolumn{7}{|c|}{ Deo river section } \\
\hline & $\mathrm{H} / 1 / 1$ & $\mathrm{H} / 1 / 2$ & $\mathrm{H} / 1 / 3$ & $\mathrm{H} / 1 / 4$ & $\mathrm{H} / 1 / 5$ & Average & $\mathrm{H} / 2 / 1$ & $\mathrm{H} / 2 / 2$ & $\mathrm{H} / 2 / 3$ & $\mathrm{H} / 2 / 4$ & $\mathrm{H} / 2 / 5$ & $\mathrm{H} / 2 / 6$ & Average \\
\hline $\mathrm{SiO}_{2}$ & 50.34 & 51.21 & 49.37 & 54.46 & 52.35 & 51.55 & 57.70 & 57.78 & 55.21 & 59.70 & 60.12 & 56.71 & 57.87 \\
\hline $\mathrm{TiO}_{2}$ & 0.04 & 0.04 & 0.02 & 0.03 & 0.03 & 0.03 & 0.00 & 0.00 & 0.00 & 0.00 & 0.00 & 0.00 & 0.00 \\
\hline $\mathrm{Al}_{2} \mathrm{O}_{3}$ & 0.24 & 0.23 & 0.30 & 0.25 & 0.25 & 0.25 & 0.21 & 0.32 & 0.11 & 0.10 & 0.18 & 0.24 & 0.19 \\
\hline $\mathrm{Fe}_{2} \mathrm{O}_{3}$ & 48.71 & 47.87 & 49.83 & 44.60 & 47.04 & 47.61 & 41.96 & 41.75 & 44.51 & 40.09 & 39.61 & 42.95 & 41.81 \\
\hline $\mathrm{MnO}$ & 0.01 & 0.01 & 0.05 & 0.03 & 0.03 & 0.03 & 0.00 & 0.00 & 0.00 & 0.00 & 0.00 & 0.00 & 0.00 \\
\hline $\mathrm{MgO}$ & 0.09 & 0.10 & 0.13 & 0.10 & 0.12 & 0.11 & 0.07 & 0.07 & 0.08 & 0.07 & 0.07 & 0.07 & 0.07 \\
\hline $\mathrm{CaO}$ & 0.21 & 0.21 & 0.13 & 0.21 & 0.10 & 0.17 & 0.04 & 0.04 & 0.04 & 0.04 & 0.04 & 0.04 & 0.04 \\
\hline $\mathrm{Na}_{2} \mathrm{O}$ & 0.00 & 0.00 & 0.00 & 0.00 & 0.00 & 0.00 & 0.00 & 0.00 & 0.00 & 0.00 & 0.00 & 0.00 & 0.00 \\
\hline $\mathrm{K}_{2} \mathrm{O}$ & 0.00 & 0.00 & 0.00 & 0.00 & 0.00 & 0.00 & 0.00 & 0.00 & 0.00 & 0.00 & 0.00 & 0.00 & 0.00 \\
\hline $\mathrm{P}_{2} \mathrm{O}_{5}$ & 0.22 & 0.22 & 0.24 & 0.22 & 0.23 & 0.23 & 0.03 & 0.04 & 0.03 & 0.02 & 0.02 & 0.05 & 0.03 \\
\hline Total & 100.03 & 100.06 & 100.07 & 99.90 & 100.15 & & 100.01 & 100.00 & 99.98 & 100.02 & 100.04 & 100.06 & \\
\hline
\end{tabular}

Noamundi

Garumahishani (silicate facies)

\begin{tabular}{lrrrrrrrrrrrr}
\hline & $\mathrm{H} / 3 / 1$ & $\mathrm{H} / 3 / 2$ & $\mathrm{H} / 3 / 3$ & $\mathrm{H} / 3 / 4$ & $\mathrm{H} / 3 / 5$ & Average & $\mathrm{H} / 5 / 1$ & $\mathrm{H} / 5 / 2$ & $\mathrm{H} / 5 / 3$ & $\mathrm{H} / 5 / 4$ & $\mathrm{H} / 5 / 5$ & Average \\
\hline $\mathrm{SiO}_{2}$ & 62.71 & 62.74 & 58.85 & 60.82 & 64.86 & 62.00 & 70.72 & 68.82 & 67.24 & 67.77 & 66.02 & 68.11 \\
$\mathrm{TiO}_{2}$ & 0.03 & 0.02 & 0.03 & 0.03 & 0.04 & 0.03 & 0.06 & 0.05 & 0.06 & 0.06 & 0.05 & 0.06 \\
$\mathrm{Al}_{2} \mathrm{O}_{3}$ & 0.38 & 0.35 & 0.25 & 0.25 & 0.30 & 0.31 & 0.10 & 0.36 & 0.30 & 0.42 & 0.25 & 0.29 \\
$\mathrm{Fe}_{2} \mathrm{O}_{3}$ & 36.79 & 36.69 & 40.71 & 38.79 & 35.62 & 37.72 & 29.12 & 30.72 & 32.22 & 31.67 & 33.64 & 31.47 \\
$\mathrm{MnO}$ & 0.00 & 0.00 & 0.00 & 0.00 & 0.00 & 0.00 & 0.01 & 0.02 & 0.02 & 0.02 & 0.02 & 0.02 \\
$\mathrm{MgO}$ & 0.08 & 0.08 & 0.09 & 0.09 & 0.08 & 0.08 & 0.01 & 0.06 & 0.07 & 0.03 & 0.05 & 0.04 \\
$\mathrm{CaO}$ & 0.00 & 0.00 & 0.00 & 0.00 & 0.00 & 0.00 & 0.02 & 0.04 & 0.06 & 0.05 & 0.05 & 0.04 \\
$\mathrm{Na}_{2} \mathrm{O}$ & 0.00 & 0.00 & 0.00 & 0.00 & 0.00 & 0.00 & 0.00 & 0.00 & 0.00 & 0.00 & 0.00 & 0.00 \\
$\mathrm{~K}_{2} \mathrm{O}$ & 0.00 & 0.00 & 0.00 & 0.00 & 0.00 & 0.00 & 0.00 & 0.00 & 0.00 & 0.00 & 0.00 & 0.00 \\
$\mathrm{P}_{2} \mathrm{O}_{5}$ & 0.08 & 0.12 & 0.06 & 0.05 & 0.11 & 0.08 & 0.01 & 0.02 & 0.04 & 0.01 & 0.00 & 0.02 \\
$\mathrm{Total}$ & 100.07 & 100.00 & 99.99 & 100.03 & 101.01 & & 100.05 & 100.09 & 100.01 & 100.03 & 100.08 & \\
\hline
\end{tabular}

Garumahishani (oxide facies)

FER-3 Fer-3 certified measured (CANMET)

\begin{tabular}{lrrrrrrrr}
\hline & $\mathrm{H} / 4 / 1$ & $\mathrm{H} / 4 / 2$ & $\mathrm{H} / 4 / 3$ & $\mathrm{H} / 4 / 4$ & $\mathrm{H} / 4 / 5$ & Average & & \\
\hline $\mathrm{SiO}_{2}$ & 45.85 & 44.87 & 43.56 & 45.54 & 44.67 & 44.90 & 53.24 & 53.61 \\
$\mathrm{TiO}_{2}$ & 0.00 & 0.00 & 0.00 & 0.00 & 0.00 & 0.00 & 0.02 & 0.01 \\
$\mathrm{Al}_{2} \mathrm{O}_{3}$ & 0.04 & 0.12 & 0.08 & 0.06 & 0.02 & 0.06 & 0.07 & 0.09 \\
$\mathrm{Fe}_{2} \mathrm{O}_{3}$ & 50.42 & 51.69 & 53.40 & 50.79 & 51.68 & 51.60 & 44.53 & 44.39 \\
$\mathrm{MnO}$ & 0.84 & 0.73 & 0.62 & 0.73 & 0.81 & 0.75 & 0.04 & 0.07 \\
$\mathrm{MgO}$ & 1.80 & 1.34 & 0.88 & 1.56 & 1.76 & 1.47 & 1.03 & 1.01 \\
$\mathrm{CaO}$ & 0.90 & 1.13 & 1.36 & 1.22 & 1.02 & 1.13 & 0.81 & 0.85 \\
$\mathrm{Na}$ & 0.00 & 0.00 & 0.00 & 0.00 & 0.00 & 0.00 & 0.02 & 0.03 \\
$\mathrm{~K}_{2} \mathrm{O}$ & 0.08 & 0.08 & 0.01 & 0.05 & 0.06 & 0.06 & 0.03 & 0.03 \\
$\mathrm{P}_{2} \mathrm{O}_{5}$ & 0.08 & 0.08 & 0.10 & 0.06 & 0.04 & 0.07 & 0.04 & 0.07 \\
$\mathrm{Total}$ & 100.01 & 100.04 & 100.01 & 100.01 & 100.06 & & 100.31 & 100.16 \\
\hline
\end{tabular}

Tasmania University, Australia. Prior to analysis by LA-ICPMS, the oxide grains were analyzed by electron microprobe (CAMECA SX100) to obtain the iron content, which was used as an internal standard. A laser beam diameter size of 10 or $8 \mu \mathrm{m}$ was used to ablate the core and margin portions of the iron-oxide grains to counter redistribution of trace and REE during post-depositional alteration. A synthetic standard was analyzed regularly after five spot analyses of the samples to check the accuracy. The resulting precision was better than $10 \%$ (2 standard deviation) for most 
of the elements. The use of LA-ICPMS technique yielded for the first time, a more complete and precise trace and REE dataset (with accuracy of second decimal level) for the oxide phases of banded iron-formations of the Iron Ore Group of Jharkhand-Orissa region of eastern India. In the absence of phosphatic mineral grains within the iron oxide rich bands, the trace and REE chemistry of the oxide phases is considered to represent the chemistry of the contemporaneous bottom seawater from which the iron-oxyhydroxides were precipitated. The major element chemistry of the banded iron-formations, and the trace and REE chemistry of the iron oxide phases are listed in tables 1 and 2 .

\subsection{Major element chemistry of the banded iron-formations}

Major element chemistry of the five banded ironformation horizons from four different localities is shown in table 1. A comparison (figure 4) of the major element chemistry of the studied samples with the average major element chemistry of the unaltered oxide facies banded iron-formation of the Transvaal Supergroup, South Africa (data from Klein and Beukes 1989) reveals the unaltered nature of the studied banded iron-formations. $\mathrm{SiO}_{2}$ and $\mathrm{Fe}_{2} \mathrm{O}_{3}$ constitute nearly 98 to $99 \%$ of the bulk of the banded iron-formation. $\mathrm{SiO}_{2}$ and $\mathrm{Fe}_{2} \mathrm{O}_{3}$ content of the studied banded iron-formations have an inverse relationship to each other. $\mathrm{Al}_{2} \mathrm{O}_{3}$ content varies between 0.06 and $0.42 \%$. Except silicate facies iron-formation of Garumahishani, $\mathrm{Na}_{2} \mathrm{O}$ and $\mathrm{K}_{2} \mathrm{O}$ contents are very low or even undetectable in the studied samples. $\mathrm{P}_{2} \mathrm{O}_{5}$ contents in the banded iron-formations range between 0.24 and $0.01 \%$, and the highest values occur in the Gandhamardan samples. $\mathrm{MnO}_{2}$ content (except in the Garumahishani oxide facies iron-formation with $\mathrm{MnO}_{2} \approx 0.75 \%$ ) is below detection limit in all the bulk banded iron-formation samples studied for major elements. $\mathrm{MgO}(0.88-1.80 \%)$ and $\mathrm{CaO}$ $(2.60-0.08 \%)$ contents are significantly very low.

\subsection{Trace element chemistry of the iron-oxide phases}

The trace element chemistry of iron oxide phases of the studied banded iron-formations (table 2) show significant variations. As/Ti, Ba/Ge, V/Ti and $\mathrm{Sn} / \mathrm{As}$ variation diagrams (figure 5 ) show pronounced clustering of selected trace element ratio plots of iron oxide phases of different banded ironformation horizons. Iron oxide phases of the Deo Nala section banded iron-formations show enrichment with respect to $\mathrm{Mo}, \mathrm{Sn}, \mathrm{W}, \mathrm{As}$ and $\mathrm{Pb}$ (figure 6), where $\mathrm{V}, \mathrm{As}, \mathrm{Ni}$ and $\mathrm{Cr}$ contents are as high as those in the Gandhamardan samples (table 2). Trace element contents of the magnetites from the Garumahishani silicate facies iron-formation differ largely from the magnetites of the oxide facies iron-formation (figure 7). Concentrations of $\mathrm{Ti}, \mathrm{V}$, $\mathrm{Cr}, \mathrm{Mn}$ and $\mathrm{Ni}$ are roughly an order of magnitude higher in silicate facies magnetites.

\subsection{Rare earth elements chemistry of the iron-oxide phases}

The REE contents and PASS-normalized REE pattern of iron oxide phases of the studied banded iron-formations are given in table 2 and figure 8 . The total REE content of different oxide phases varies from 0.55 to $13.79 \mathrm{ppm}$, and the low values are comparable to the total REE content of other Archean banded iron-formations (see Fryer 1977; Majumder et al 1984; Rao and Naqvi 1995; Kato et al 1996). The REE patterns show conspicuous enrichment of HREE in the studied iron-formation horizons. Martitized magnetites of Gandhamardan show strong positive Eu anomaly $\left(\mathrm{Eu} / \mathrm{Eu}^{*}=2.58\right.$ to 2.67). REE patterns of martitized magnetites of the Deo Nala section show La enrichment (avg. $\left.\mathrm{La} / \mathrm{La}^{*}=1.87\right)$ and small but detectable positive Eu anomaly (1.87-2.29). Noamundi hematites and martitized magnetites show positive Eu anomalies (1.95-2.16). Magnetites of Gorumahishani oxide facies iron-formation show incipient positive Eu anomalies (0.90-2.64). Gorumahishani silicate facies magnetites show strong positive Eu anomaly (2.90-3.17). Ce anomalies in the studied samples are insignificant and range between -0.07 and +0.03 .

\section{Discussion}

Major, trace and REE chemistry of marine precipitates, like banded iron-formation, provides a record of certain aspects of seawater composition through Earth's history (Klein and Beukes 1989; Derry and Jacobsen 1990; Morris 1993; Bau and Dulski 1996; Bolhar et al 2004; Polat and Frei 2005). The geochemical database on the banded iron-formations of Jharkhand-Orissa region could potentially contribute to the characterization of archean bottom seawater.

High contents of $\mathrm{SiO}_{2}$ and $\mathrm{Fe}_{2} \mathrm{O}_{3}$ in the studied banded iron-formations signify the purity of the chemical precipitates. Low $\mathrm{Al}_{2} \mathrm{O}_{3}$ content of the banded iron-formations (0.06 to $0.42 \%$ ) further attests to the detritus-free nature of the silica-iron precipitates. Very small to undetectable $\mathrm{Na}_{2} \mathrm{O}$ and $\mathrm{K}_{2} \mathrm{O}$ contents (except the silicate facies iron-formation of Garumahishani) may further indicate that contamination by pyroclastic debris was minimum during the precipitation of the 


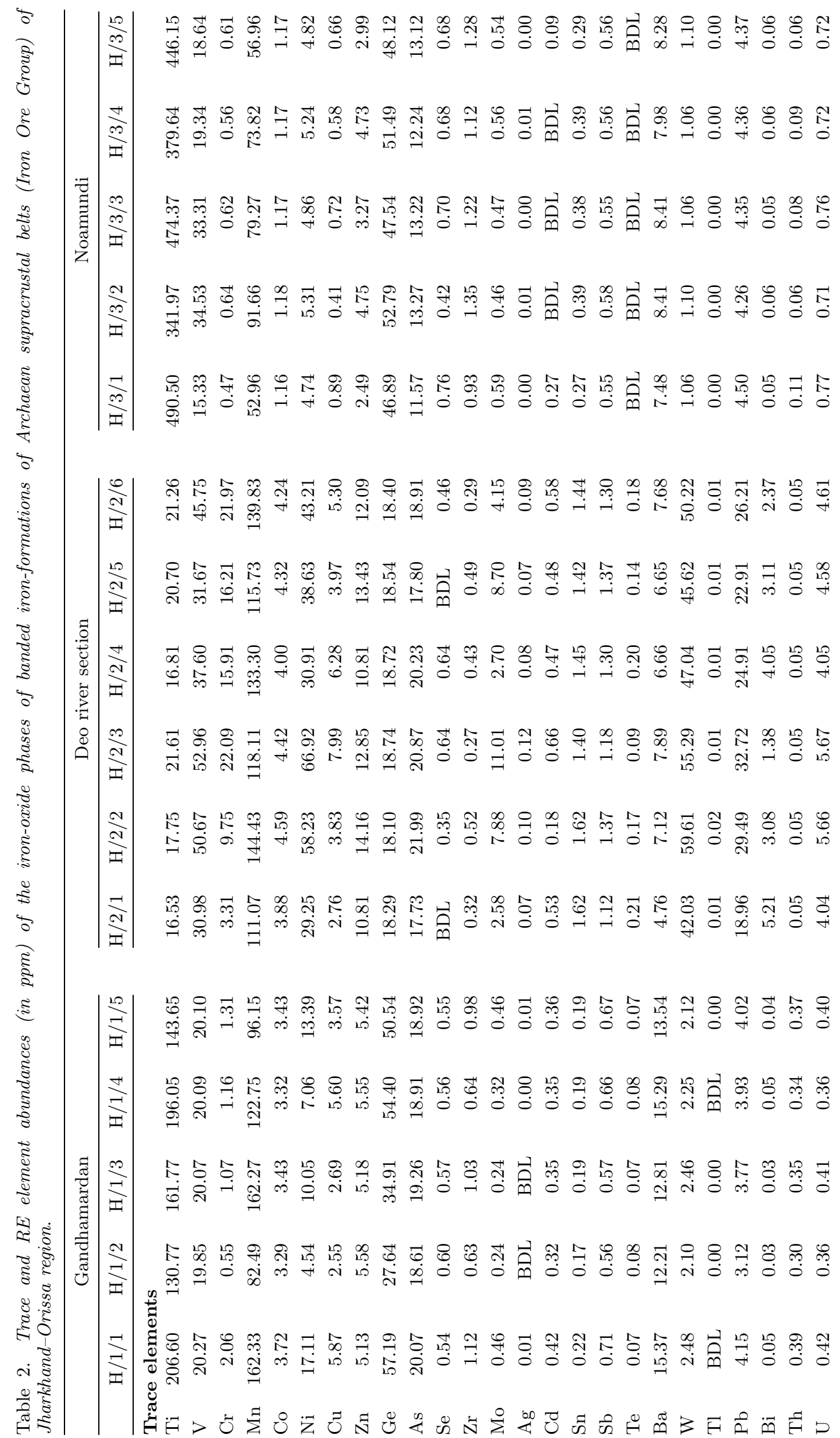




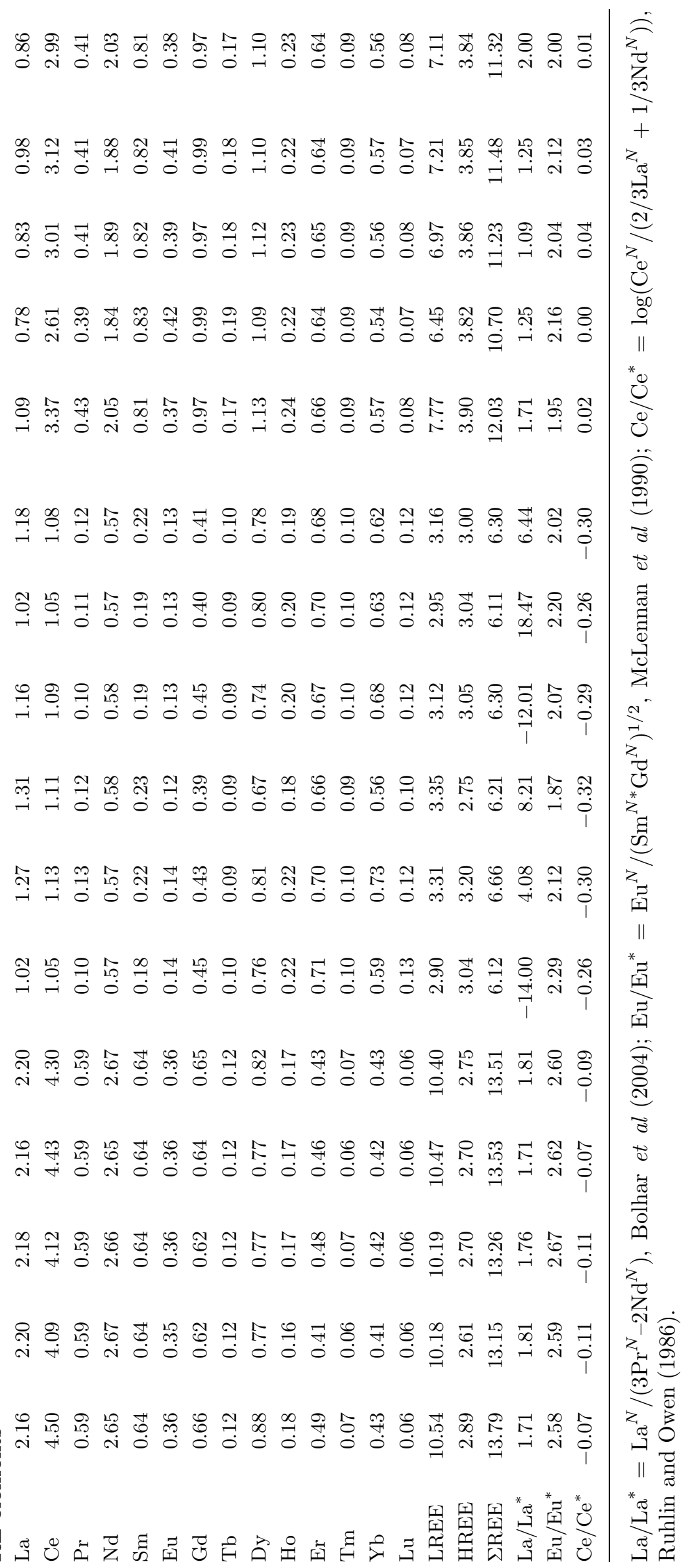




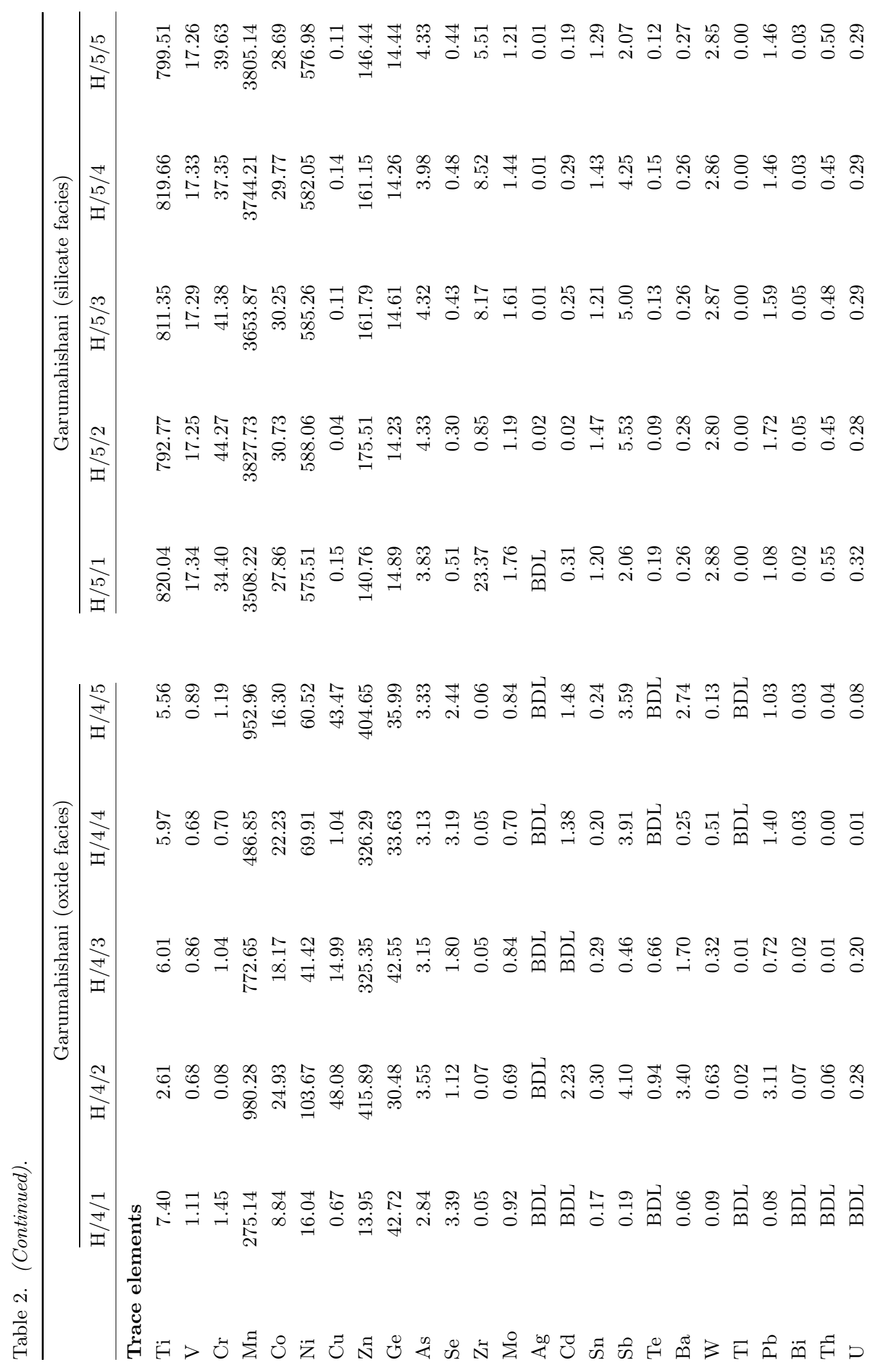




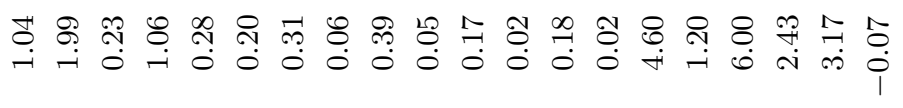

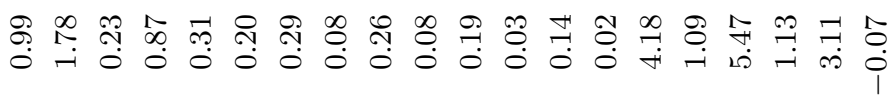

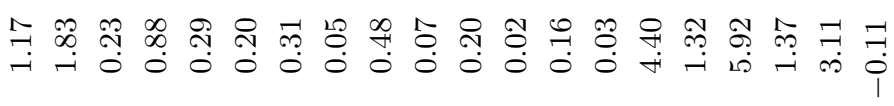

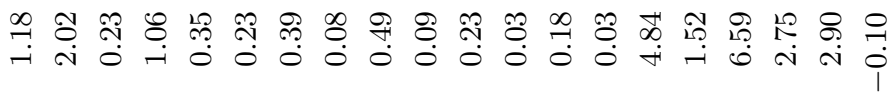

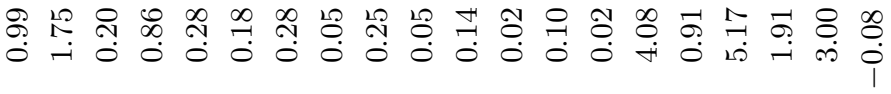

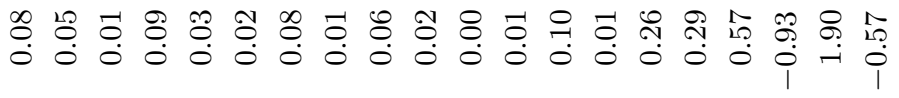

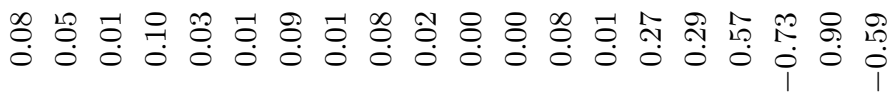

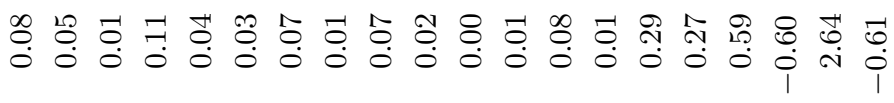

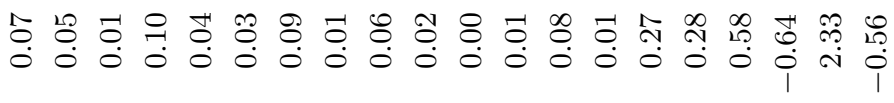

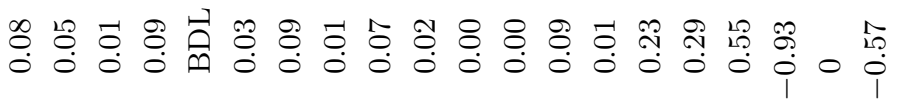
告

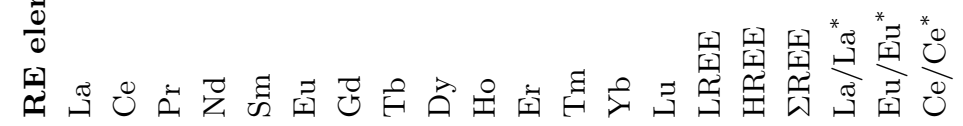




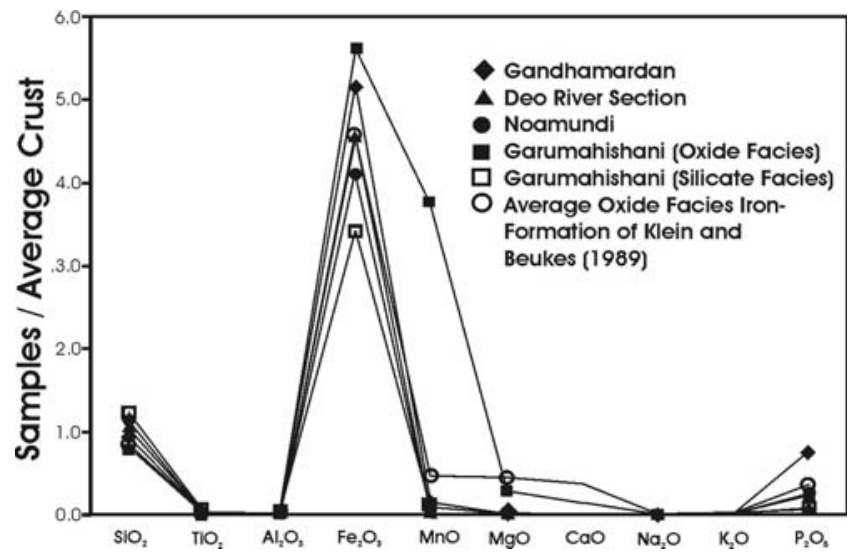

Figure 4. Plots of average crust normalized major elements of the studied banded iron-formations and the average values of oxide facies iron-formations are from Klein and Beukes (1989).

banded iron-formations. The silicate facies ironformation of Garumahishani, with average 1\% $\mathrm{Na}_{2} \mathrm{O}$, might have incorporated a minor amount of pyroclastic debris. Very low amount of $\mathrm{MgO}$ and $\mathrm{CaO}$ suggest the presence of minor dolomitic carbonates in the banded iron-formations.

Variation in concentrations of certain trace elements in the oxide phases of studied banded iron-formation horizons attest to differences in depositional and diagenetic or metamorphic conditions. Mo, Sn, W, As and $\mathrm{Pb}$ are usually associated with felsic components, whereas $\mathrm{V}, \mathrm{Ni}$ and $\mathrm{Cr}$ are typical of mafic sources. The occurrence of the Deo Nala section banded iron-formations as rafts within intrusive granites might explain their high contents by hydrothermal metasomatic alterations, whereas $\mathrm{V}, \mathrm{Ni}$ and $\mathrm{Cr}$ remained essentially unaffected. Higher concentrations of $\mathrm{Ti}, \mathrm{V}, \mathrm{Cr}, \mathrm{Mn}$ and $\mathrm{Ni}$ in Garumahishani silicate facies iron-formation with respect to other studied banded iron-formations are significant. A possible explanation for these higher concentrations would be the influx of high-temperature metalliferous hydrothermal brine produced from rock-water interaction in the spreading related mafic-ultramafic oceanic crust, and/or mixing of mafic-ultramafic debris derived from weathering of oceanic crust.

$(\mathrm{Co}+\mathrm{Cu}+\mathrm{Ni}) / \Sigma \mathrm{REE}$ plots are used to discriminate hydrothermal from hydrogenous deposits in recent settings (Dymek and Klein 1988). This variation diagram has been successfully used by several workers to distinguish between two deposit types in Precambrian settings as well (see Klein and Beukes 1989). All the samples of the present study fall within or close to the hydrothermal field (figure 9), which also suggest that a major part of
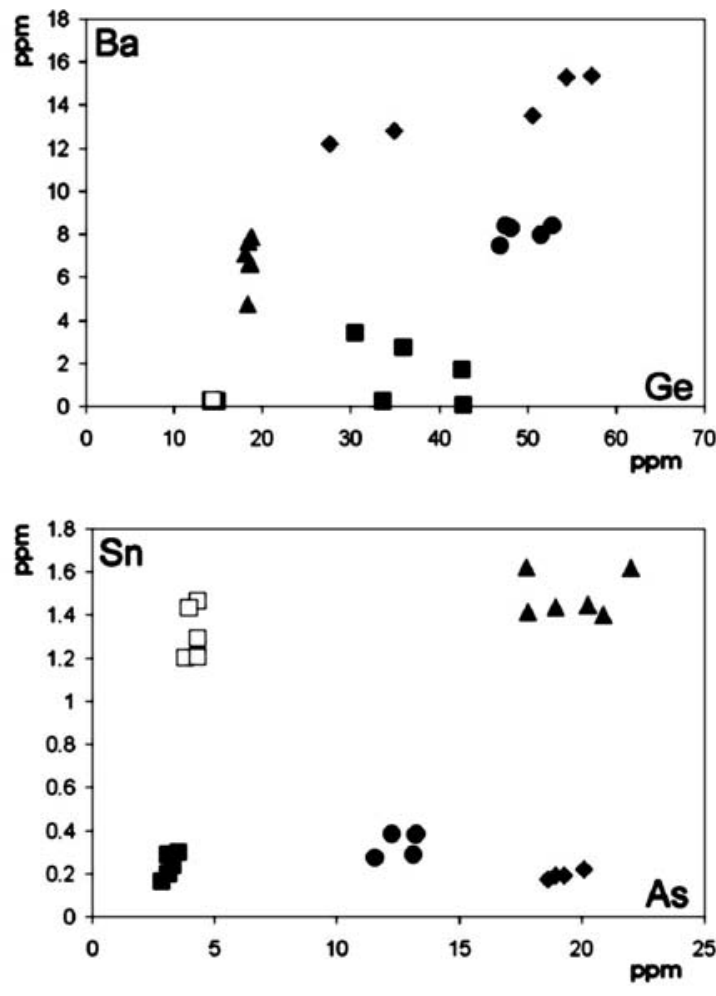

- Noamundi

- Deo Nala

\section{Gandhamardan}

Figure 5. As/Ti, Ba/Ge, $\mathrm{V} / \mathrm{Ti}$ and $\mathrm{Sn} / \mathrm{As}$ plots of oxide phases of the banded iron-formations showing conspicuous variations in trace element contents. 

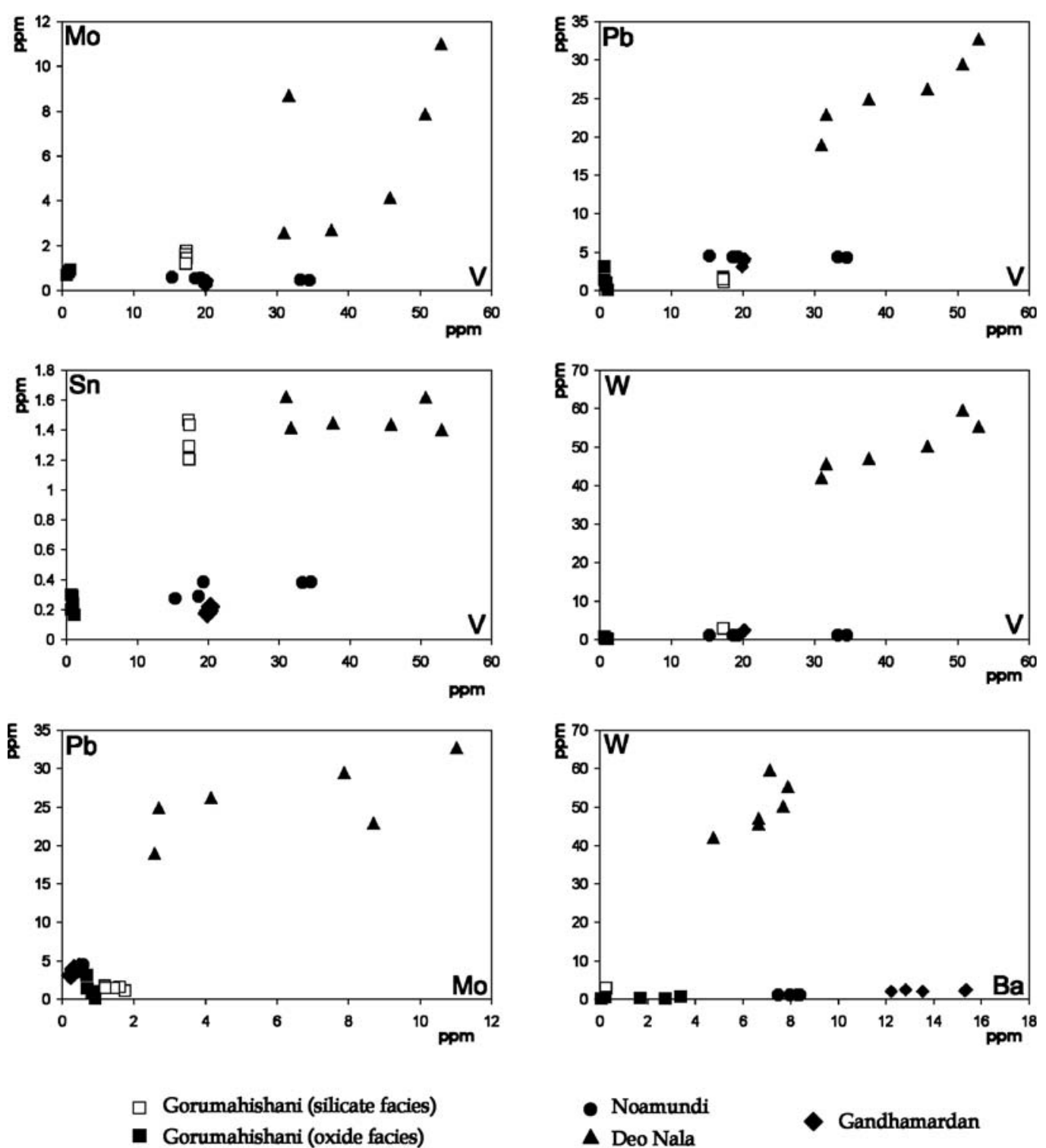

- Noamundi

$\Delta$ Deo Nala

Figure 6. $\mathrm{Mo} / \mathrm{V}, \mathrm{Pb} / \mathrm{V}, \mathrm{Sn} / \mathrm{V}, \mathrm{W} / \mathrm{V}, \mathrm{Pb} / \mathrm{Mo}$ and $\mathrm{W} / \mathrm{Ba}$ plots of oxide phases of the banded iron-formations. Note distinctly different trace element abundance in Deo Nala samples.

the metals in the studied banded iron-formations were added to the bottom seawater by hydrothermal solutions derived from hydrothermally active marine environments, for example mid-oceanic ridges. It is pertinent to note that according to Klein and Beukes (1989), deposition from an admixture of East Pacific Rise hydrothermal fluids and North Atlantic seawater in 1:1000 ratio will yield $\Sigma$ REE and positive Eu anomalies identical to those observed in banded iron-formations.

The present day hydrothermal $\mathrm{Fe}$ flux $\left(\sim 4.10^{10} \mathrm{~mol} \mathrm{Fe} / \mathrm{y}\right)$ is insufficient to supply the quantity of $\mathrm{Fe}$ found in Archean banded ironformations (Jacobsen and Pimentel-Klose 1988; Kump and Holland 1992). Using estimates for the extent of banded iron-formations and rate of deposition a mass flux of $\mathrm{Fe} \sim 10^{13} \mathrm{~g} / \mathrm{y}$ was likely to have persisted during precipitation of banded iron-formation in Archean times (Trendall and Blockley 1970; James 1983; Klein and Beukes 1989). Considering the temperature-dependence of $\mathrm{Fe}$ precipitation in hydrothermal fluids it is assumed that the temperatures during the exhalation of the fluids were much higher in the Archean and this could potentially explain the large quantity of $\mathrm{Fe}$ preserved in banded iron-formations (Alibert and McCulloch 1993).

A pronounced enrichment of the HREE relative to the LREE in the studied banded ironformations mimics the distribution pattern of REEs in the marine environment (see Ruhlin and Owen 1986). Positive Eu anomalies of banded ironformations have been attributed to hydrothermal fluids (Michard and Albarede 1986; Campbell et al 

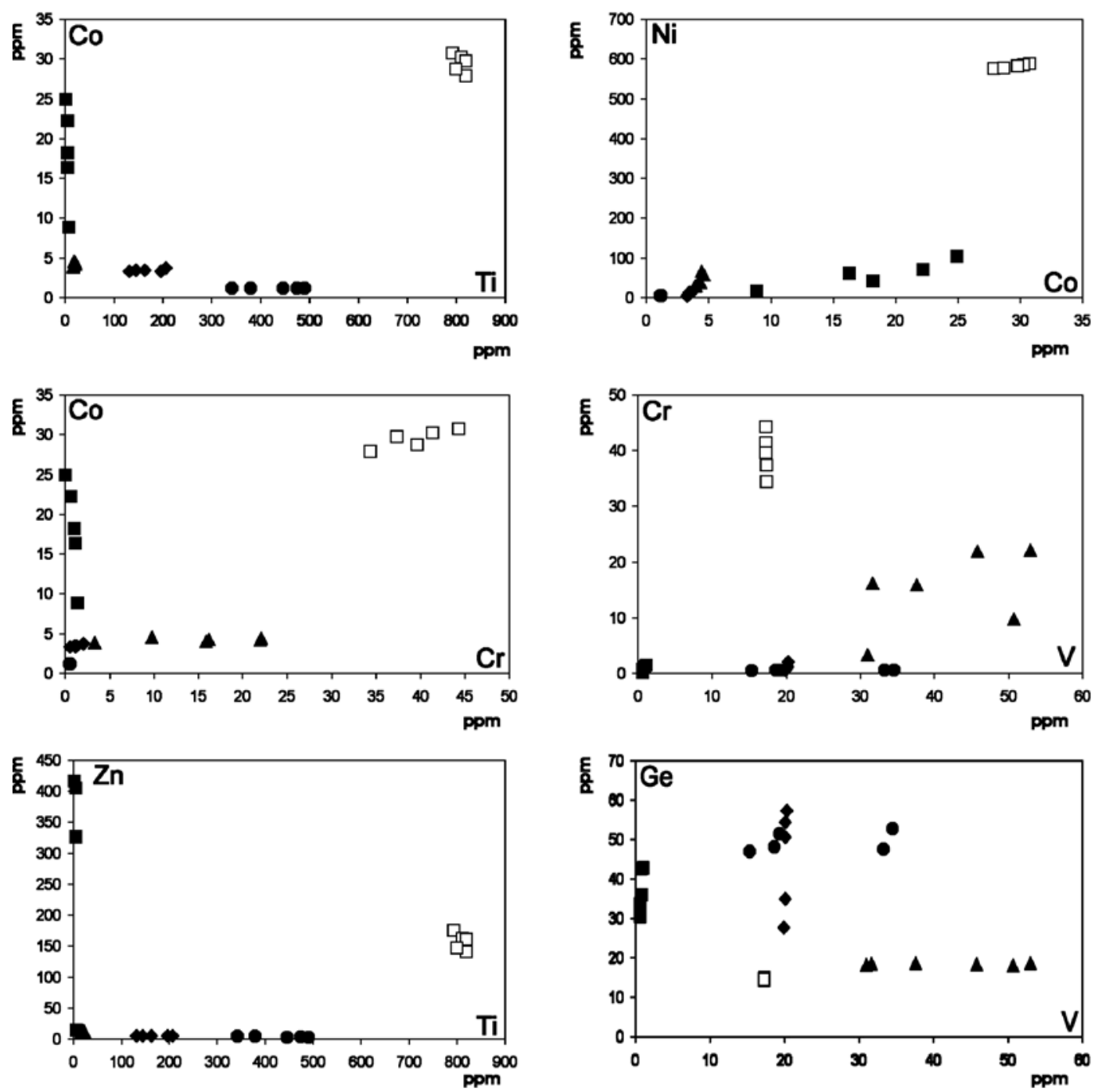

$\square$ Gorumahishani (silicate facies)

- Gorumahishani (oxide facies)

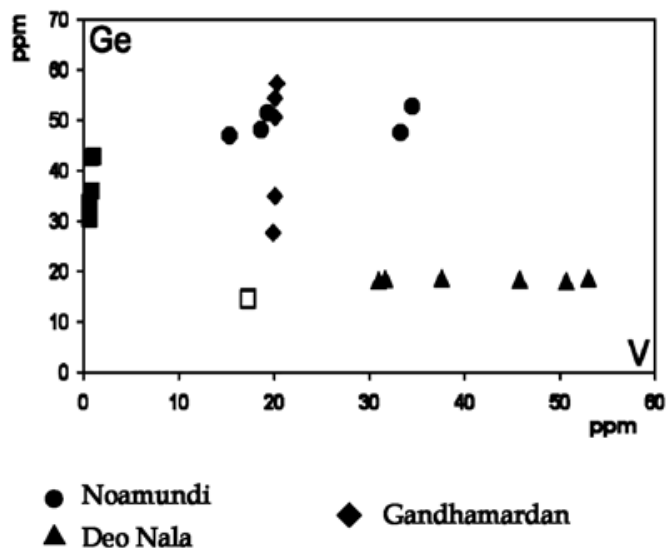

Figure 7. $\mathrm{Co} / \mathrm{Ti}, \mathrm{Ni} / \mathrm{Co}, \mathrm{Co} / \mathrm{Cr}, \mathrm{Cr} / \mathrm{V}, \mathrm{Zn} / \mathrm{Ti}$ and Ge/V plots of oxide phases of the banded iron-formations. Note distinctly different trace element abundance in magnetites of oxide facies and silicate facies iron-formations of Gorumahishani.

1988; Bau and Dulski 1996) and/or to effects of contamination of detrital felsic sediments (Rao and Naqvi 1995; Kato et al 1996). Since the $\mathrm{Al}_{2} \mathrm{O}_{3}$ content of the banded iron-formations are very low, it is unlikely that the positive Eu anomaly is caused by detrital felsic components, rather by the hydrothermal fluids. Positive Eu anomalies in the studied banded iron-formations range from 0.90 to 3.17. While addressing the variability of Eu anomalies in banded iron-formations, Bau and Moller (1993) and Bau and Dulski (1996) argued that variable $\mathrm{Eu}$ anomalies might reflect fluctuations of the mixing ratios of high-temperature and lowtemperature hydrothermal fluids. The observed variation in Eu anomaly (0.86 avg.) values between present-day hydrothermal solutions from the East Pacific Rise (Michard and Albarede 1986) and hydrothermal iron-rich sediments from close by locales $\mathrm{Eu} / \mathrm{Eu}^{*}=0.03$ (proximal) to 0.14 (distal); Ruhlin and Owen 1986 and Olivarez and Owen 1991) further indicates changing mixing ratios between hydrothermal fluids and ambient bottom seawaters as the cause of variation in Eu anomaly.

In this context, variable positive $\mathrm{Eu}$ anomalies in the studied samples strongly support exhalation of hydrothermal fluids with variable temperatures and that was the potential to supply the large quantity of Fe for the banded iron-formations of the Jharkhand-Orissa region. Diagenetic fluids and fluvial discharge into the ocean possibly played a subdued role in contributing REE and metal budget of the sea bottom water.

Present day seawater exhibits a generally strong Ce negative anomaly, which is a result of $\mathrm{Ce}$ 

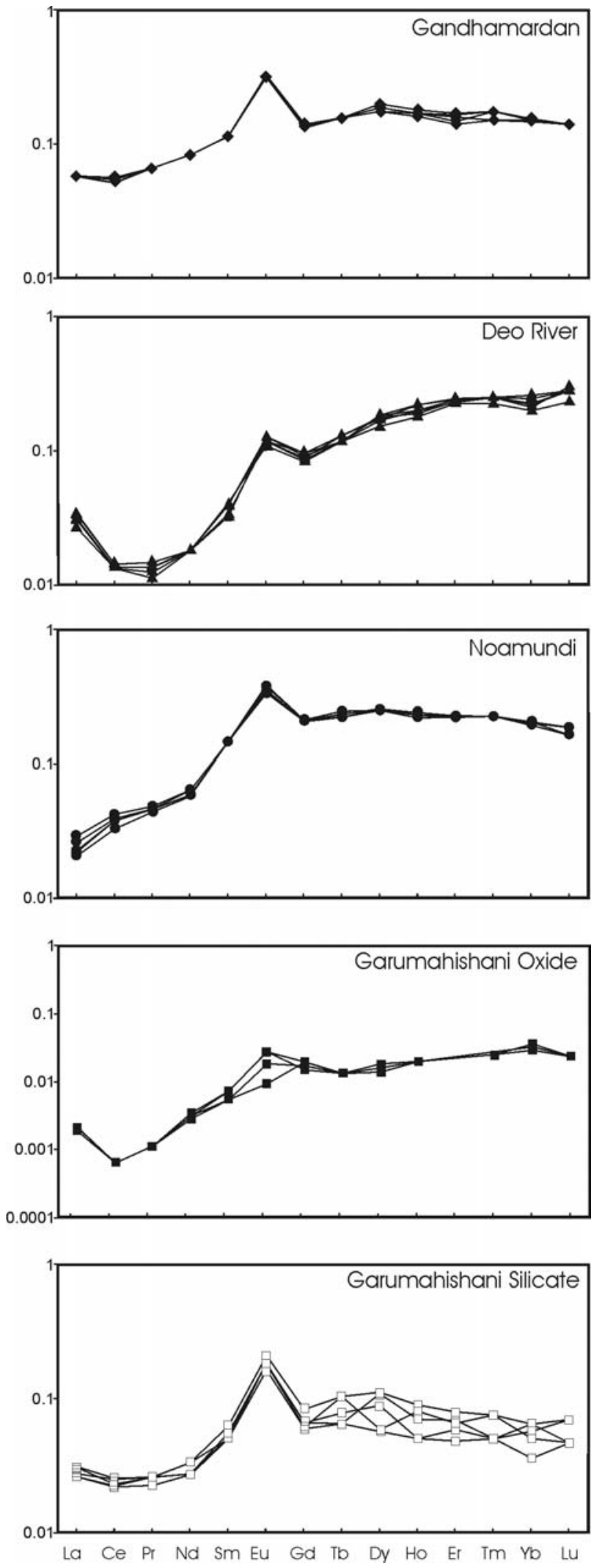

Figure 8. PAAS-normalized REE patterns of the oxide phases of the banded iron-formations.

oxidation and removal (Elderfield and Greaves 1982; De Baar et al 1985). Further it is observed that the anoxic seawater of the Cariaco Trench
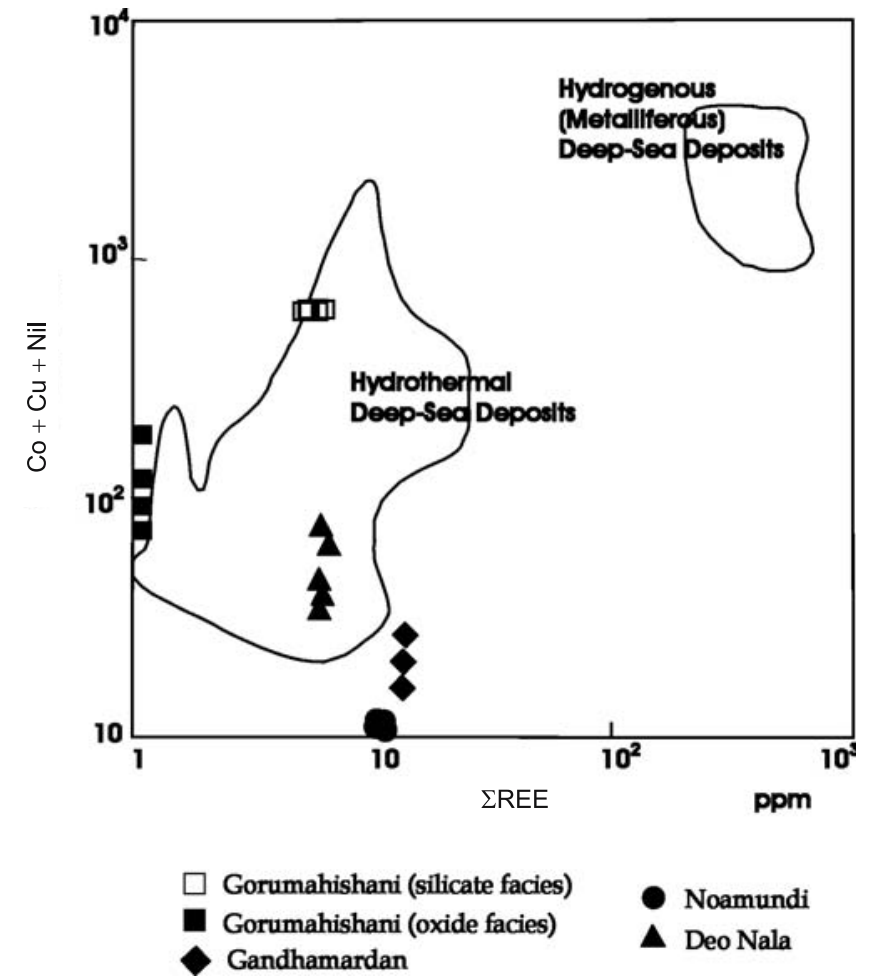

- Noamundi

$\Delta$ Deo Nala

Figure 9. $\quad$ RREE vs. $\mathrm{Co}+\mathrm{Cu}+\mathrm{Ni}$ plots of the oxide phases of the banded iron-formations. Note that the samples fall within or close to the field of hydrothermal deposits.

(southeast of Caribbean shelf, Venezuela) exhibits a slightly positive or no Ce anomaly, in contrast to overlying oxic water with a negative Ce anomaly (in Kato et al 1996). By analogy, nonexisting anomaly of $\mathrm{Ce}$ in the studied iron oxide phases of the banded iron-formations of Jharkhand-Orissa region also suggest that the contemporaneous sea bottom water was anoxic (also see Bau and Dulski 1996). The huge flux of reduced $\mathrm{Fe}$ and other species into the seawater could have been a major oxygen sink, which indulged the anoxic character of the bottom seawater during the Precambrian.

\section{Conclusion}

Geochemistry of banded iron-formations of the Jharkhand-Orissa region is detritus-free chemical precipitates. Trace and REE patterns with strong Eu anomalies of the iron oxide phases of the studied banded iron-formations indicate basinal hydrothermal fluids as source for the major part of the Fe, other trace and REEs to the bottom seawater. Variable Eu anomalies in the studied samples further indicate mixing of hydrothermal fluids of different temperatures with the bottom seawater, rather than variable admixture of felsic components. Influx of reduced Fe in the seawater acted as a major oxygen sink, and the nonexisting 
Ce anomaly in the studied banded iron-formations attest to an anoxic nature of the Archean bottom sea water.

\section{Acknowledgements}

The first author (HB) is grateful to Prof. Ross Large, Director, CODES Special Research Centre, and Tasmania University, Australia for a visitorship and allowing him to work in the LA-ICPMS Lab. Dr Kaushik Das, Indian School of Mines, is hereby acknowledged for arranging major element analysis of the collected samples. An earlier version of the manuscript was much improved through reviews by Dr Michael Bau (IU Bremen), Dr S Banerjee (IIT, Mumbai) and Dr J Gutzmer (JU, South Africa). We express our sincere thanks to Dr Robert Frei (UC, Denmark) and an anonymous reviewer for their extremely helpful reviews.

\section{References}

Alibert C and McCulloch M T 1993 Rare earth element and neodymium composition of the Banded Iron Formation and associated shales from the Hamersley, Western Australia; Geochim. Cosmochim. Acta $\mathbf{5 7}$ 187-204.

Banerji A K 1977 On the Precambrian Banded IronFormation and manganese ores of Singhbhum region, Eastern India; Econ. Geo. 72 90-98.

Bau M and Dulski P 1996 Distribution of yttrium and rareearth elements in the Penge and Kuruman Iron Formation, Transval Supergroup, South Africa; Precamb. Res. $7937-55$.

Bau M and Möller P 1993 Rare-earth element systematics of the chemically precipitated components in Early Precambrian iron formations and the evolution of the terrestrial atmosphere-hydrosphere-lithosphere system; Geochim. Cosmochim. Acta 57 2239-2249.

Bolhar R, Kamber B S, Moorbath S, Fedo C M, Whitehouse M J 2004 Characterisation of early Archean chemical sediments by trace elements; Earth Planet. Sci. Lett. 222 43-60.

Campbell A C, Palmer M R, Klinkhammer G P, Bowers T S, Edmond J M, Lawrence J R, Casey J F, Thompson G, Humphris S, Rona P and Karson J A 1988 Chemistry of hot springs on the Mid-Atlantic Ridge; Nature 335 $514-519$.

CANMET Mining and Mineral Sciences Laboratories (CCRMP) 2006555 Booth Street, Ottawa Ontario, Canada K1A0G1.

Danielson A, Moller P and Dulski P 1992 The europium anomalies in banded iron formations and the thermal history of the oceanic crust; Chem. Geol. 97 89-100.

De Baar H J W, Bacon M P and Brewer P G 1985 Rare earth elements in the Pacific and Atlantic Oceans; Geochim. Cosmochim. Acta 49 1943-1959.

Derry L A and Jacobsen S B 1990 The chemical evolution of Precambrian seawater: evidence from REEs in banded iron formations; Geochim. Cosmochim. Acta $\mathbf{5 4}$ 2965-2977.
Dymek R F and Klein C 1988 Chemistry, petrology and origin of banded iron formation lithologies from the $3800 \mathrm{Ma}$ Isua supracrustal belt, West Greenland; Precamb. Res. 39 247-302.

Elderfield H and Greaves M J 1982 The rare earth elements in seawater; Nature 296 214-219.

Fryer B J 1977 Rare earth evidence in iron-formations for changing Precambrian oxidation states; Geochim. Cosmochim. Acta 41 361-367.

Graf Jr J L 1978 Rare earth elements, iron formations and sea water; Geochim. Cosmochim. Acta 42 1845-1850.

Jacobsen S B and Pimentel-Klose M R 1988 A Nd isotopic study of the Hamersley and Michipicoten banded iron formations: The source of REE and Fe in Archaean oceans; Earth Planet. Sci. Lett. 87 29-44.

James H L 1954 Sedimentary facies of iron-formations; Econ. Geol. 49 235-293.

James H L 1983 Distribution of Banded Iron-Formation in space and time. In: Iron-formation: Facts and Problems (eds) Trendall A F and Morris R C (Amsterdam: Elsevier) 471-490.

Kato Y, Kawakami T, Kano T, Kunugiza K and Swamy N S 1996 Rare-earth element geochemistry of banded iron formations and associated amphibolite from the Sargur belts, South India; J. Southeast Asian Earth Sci. 14 161-164.

Klein C and Beukes N J 1989 Geochemistry and sedimentology of a facies transition from limestone to ironformation deposition in the Early Proterozoic Transvaal Supergroup, South Africa; Econ. Geol. 84 1733-1774.

Kump L R and Holland H D 1992 Iron in Precambrian rocks: implications for the global oxygen budget of the ancient Earth; Geochim. Cosmochim. Acta 56 3217-3223.

Majumder T, Chakraborty K L and Bhattacharjee A 1982 Geochemistry of Banded Iron-Formation of Orissa, India; Mineral. Deposit. 17 107-118.

Majumder T, Whitley J E and Chakraborty K L 1984 Rare-earth elements in the Indian banded iron formation; Chem. Geol. 45 203-211.

McLennan S M, Taylor S R, McCulloch M T and Maynard J B 1990 Geochemical and Nd-Sr isotopic composition of deep-turbidites: crustal evolution and plate tectonic associations; Geochim. Cosmochim. Acta $\mathbf{5 4}$ 2015-2050.

Melnik Y P 1982 Precambrian Banded Iron Formation physico-chemical conditions of formation. (Amsterdam: Elsevier) 310pp.

Michard A and Albarede F 1986 The REE content of some hydrothermal fluids; Chem. Geol. 55 51-60.

Moorbath S and Taylor P N 1988 Early Precambrian crustal evolution in eastern India: the age of the Singhbhum Granite and included remnants of older gneiss (Abs.) J. Geol. Soc. India 31 82-84.

Morris R C 1993 Genetic modeling for banded ironformation of the Hamersley Group, Pilbara Craton, western Australia; Precamb. Res. 60 243-286.

Olivarez A M and Owen R M 1991 The europium anomaly of seawater: implications for fluvial versus hydrothermal REE inputs to the oceans; Chem. Geol. 92 317-328.

Paul D K, Mukhopadhyay D, Pyne T K and Bishui P K $1991 \mathrm{Rb}-\mathrm{Sr}$ Age of Granitoid in the Deo River Section, Singhbhum and its relevance to the age of iron formation; Ind. Min. 45 51-56.

Polat A and Frei R 2005 The origin of early Archaean banded iron formations and of continental crust, Isua, southern West Greenland; Precamb. Res. 138 151-175.

Rao T G and Naqvi S M 1995 Geochemistry, depositional environment and tectonic setting of the BIF's of the Late 
Archaean Chitradurga Schist Belt, India; Chem. Geol. $121217-243$.

Ruhlin D E and Owen R M 1986 The rare earth element geochemistry of hydrothermal sediments from the East Pacific Rise: examination of a seawater scavenging mechanism; Geochim. Cosmochim. Acta 50 393-400.

Saha A K 1994 Crustal Evolution of Singhbhum, North Orissa, Eastern India. Memoir of the Geological Society of India 27 341pp.

Sarkar S N and Saha A K 1962 A revision of the Precambrian stratigraphy and tectonics of Singhbhum and adjacent regions; Quart. J. Geol. Min. Met. Soc. India 34 97-167.

Trendall A F 1973 Precambrian iron-formation of Australia. Econ. Geol. 68 1023-1034.

Trendall A F and Blockley J G 1970 The iron formations of the Precambrian Hamersley Group, Western Australia; Western Australia Geological Survey Bulletin 119 $366 \mathrm{pp}$.

Trendall A F and Blockley J G 2004 Precambrian Iron Formation In: Precambrian Earth (eds) Eriskssa P G et al Tempos and Events, pp. 403-42. 